\title{
Do selvagem convertível
}

\section{Andréa Daber}

oram duas as tentativas francesas de implantação colonial no Brasil. O
estudo da primeira delas, a França Antártica (1555-1560), já foi legitimamente inserido numa perspectiva de longa duração, numa lógica de repetição que a considera análoga às efêmeras experiências coloniais francesas do Canadá (1535-1543) e da Flórida (1562-1565). ${ }^{1}$

Mas a história intramuros da colônia fundada por Villegaignon na ilhota situada na entrada da baía de Guanabara destaca-se pelo seu caráter inédito, marcado por uma acirrada discussão teológica, que reflete microscopicamente a imagem das Guerras de Religião na França.

O projeto de estabelecimento dessa "República Cristâ"2 dos trópicos contou, desde o início, com os apoios conjugados do cardeal de Lorraine e do almirante de Coligny. É graças a este que Nicolas Durand de Villegaignon conseguiu organizar com êxito um importante corpo expedicionário formado por soldados e artesãos que desembarcaram no Rio de Janeiro em 1555. Temendo, sem dúvida, a hostilidade dos portugueses, os franceses construíram um forte que recebeu o nome de Coligny. Mas Villegaignon acabou por exercer uma verdadeira ditadura no interior de sua colônia, provocando o descontentamento de vários colonos e agravando as divergências religiosas já existentes. Complôs e rebeliōes deflagraram-se, levando Villegaignon, no início do ano de 1556, a escrever a Calvino, seu condiscípulo da faculdade de direito de Orléans, pedindo-lhe que enviasse ao Rio de Janeiro um contingente de partidários da fé reformada a fim de encontrar uma solução para os conflitos que solapavam de dentro a colônia.

Assim, quatorze huguenotes, enviados por Calvino, desembarcaram em 1557 na ilhota. Contudo, a chegada de dois ministros de Genebra, Richer e Chartier, acompanhados de uma companhia formada por colonos, mulheres e artesãos não fez com que se resolvessem as dissensões que dilaceravam a França Antártica, provocando, em vez disso, a desagregação e o desencadeamento de um gravíssimo conflito religioso. 
Como resultado das discórdias religiosas e da tirania exercida por Villegaignon no interior do forte de Coligny, os calvinistas deixaram a colônia insular, buscando refúgio junto aos tupinambás em terra firme. Dentre eles estava o huguenote Jean de Léry.

Dessa singular experiência nos vem um dos mais importantes relatos sobre o Brasil do século XVI, a Histoire d'un voyage faict en la terre du Brésil, de Léry, livro que teve um sucesso editorial notável: cinco edições a partir de 1578 e ao menos outras dez, em francês e latim, até $1611 .{ }^{3} \mathrm{O}$ objetivo principal da publicação do relato foi, segundo o huguenote, o de desmentir "as mentiras e erros" contidos no livro do monge Cordelier André Thevet, Les singularitez de la France Antarctique, publicado em 1557-1558. ${ }^{4}$

A retomada dos projetos de implantação francesa no Brasil teve de esperar ainda meio século, e o segundo Brasil francês — a França Equinocial - seria, este sim, imperativamente católico.

A região visada, no norte do Brasil, era praticamente desconhecida dos portugueses, onde os franceses traficavam sem dificuldade desde longa data. A história desse empreendimento colonial francês se iniciou em 1594, quando o capitão Jacques Riffault embarcou para o Brasil "com a intenção de possíveis conquistas". ${ }^{5}$ Mas o fracasso de sua expedição o forçou a regressar à França. Entretanto, uma parte da tripulação permaneceu no local, dentre eles Charles des Vaux que, após longa estada entre os índios, decidiu voltar à França e convencer o rei Henrique IV da importância de uma campanha colonial na região. Henrique IV ordenou então ao Senhor de La Ravardière que acompanhasse Des Vaux em uma expedição de reconhecimento da "ilha de Maranhão".

Somente alguns anos mais tarde, em 1612, a França Equinocial foi fundada, contando com o apoio da monarquia, na figura da rainha regente Maria de Medicis, que nomeou os senhores de La Ravardière e de Razilly "Lugar-tenentes do Rei de França na ilha de Maranhão" e designou missionários da ordem dos Capuchinhos para exercerem o apostolado junto aos tupinambá da região.

Dessa segunda experiência colonial no Brasil resultou um importante corpus de obras impressas, composto de cartas apologéticas enviadas pelos padres Claude d'Abbeville e Arsène de Paris a seus superiores, parentes e 
amigos. As cartas fornecem testemunhos sobre a prosperidade da colônia e contêm inúmeros detalhes sobre os recursos naturais do país e sobre o bom entendimento com os índios, além das múltiplas conversões e das milagrosas curas efetuadas.

No começo de 1614 foi editada a Histoire de la mission des pères capucins en l'Isle de Maragnan et terres circonvoisines où est traicté des singularitez admirables of des moeurs merveilleuses des indiens habitants de ce païs..., ${ }^{6}$ relato completo da viagem ao Maranhão de seu autor, o reverendo padre Claude d'Abbeville, e de seu retorno à França, em 1614, acompanhado do senhor de Razilly e de seis embaixadores tupinambás. Provavelmente, a publicação deste livro visou ao mesmo objetivo do conjunto de cerimônias espetaculares celebradas em Paris no mesmo ano, como a recepção dos embaixadores no Louvre pelo rei Luís XIII e a rainha regente, e o batismo solene de três deles na igreja dos Capuchinhos. As cerimônias visavam, com efeito, encorajar novos investidores e preparar uma possível emigração para o Maranhão.

Um ano depois, en 1615, o capuchinho Yves d'Evreux publicou a sua Suitte de l'Histoire des choses mémorables advennues en Maragnan, és années 1613 \& $1614 \ldots,{ }^{7}$ obra jamais conhecida pelo público da época, uma vez que os exemplares foram destruídos no próprio ateliê de impressão do editor, François Huby. Por razões de ordem político-diplomática, relacionadas ao projeto do casamento de Luís XIII com a infanta espanhola Ana d'Áustria, a França abriu mão do projeto de implantação colonial no Brasil. Em novembro de 1615, os franceses foram definitivamente rechaçados do Maranhão pelas forças portuguesas.

\section{Humanismo missionário e política social do escambo}

A antiguidade e a extensão das relações franco-tupi, que ultrapassam os âmbitos cronológicos e geográficos restritos à presença francesa no Rio de Janeiro e no Maranhão, depõem em favor de sua solidez. Um dos primeiros textos que atestam a dimensão política da inserção dos franceses nas sociedades indígenas, e das alianças e rupturas dela decorrentes, é o famoso relato do alemão Hans Staden, Wahrhaftige Historia und beschreibung eyner Landtschafft der Wilden nacketen, Grimmigen Menschenfresser 
Leuthen... ${ }^{8}$ Aprisionado por uma tribo de "Tuppins-Inbas", Staden fornece detalhes abundantes sobre o ritual do canibalismo, proporcionais à sua vivência dramática, quando quase se tornou uma de suas vítimas. Uma das astúcias de que se valeu para escapar ao furor canibal foi a de proclamar-se "amigo dos franceses", mantendo-se, assim, vivo até a chegada das naus de França.?

De modo geral, as referências a franceses que viviam entre os selvagens $^{10}$ são freqüentes nos primeiros escritos sobre o Brasil, assim como na documentação luso-brasileira (relatos de missões jesuítas, narrativas de expedições, missivas, entre outros). ${ }^{11}$ Uma prática corrente dentre os franceses, na época, consistia em abandonar, em plena vida selvagem, meninos, provavelmente recolhidos nos portos da Normandia, para que se integrassem às sociedades indígenas, cujos costumes, diziam os rumores, compartilhavam inteiramente do casamento ao canibalismo. Uma vez integrados às tribos tupinambás aliadas, esses truchements estavam aptos a servir de intérpretes — ou línguas, em português — para os marinheiros franceses.

Não foi sem espanto que os portugueses, particularmente os religiosos, consideraram esse fenômeno de "endotismo" francês. ${ }^{12}$ Os testemunhos mais eloqüentes referem-se, obviamente, às regióes que conheceram uma presença francesa mais forte, como o Rio de Janeiro, ${ }^{13}$ e, meio século mais tarde, o Maranhão. Em carta de 1564, José de Anchieta, grande especialista da língua geral, e conhecedor da situação dos índios do sudoeste, afirmou:

A vida dos franceses que estão nesse Rio de Janeiro não somente está separada da Igreja católica, como também se tornou selvagem; eles vivem como os índios, comendo, bebendo, dançando e cantando com eles, pintando-se com suas cores negras e vermelhas, enfeitando-se com penas de aves, andando por vezes nus, vestindo apenas uma tanga e finalmente matando seus adversários segundo o ritual dos mesmos índios, e adotando nomes novos como eles, de modo que nada lhes falta senão comer carne humana $[. ..]{ }^{14}$

Essa mesma correlação entre heresia francesa e paganismo indígena é afirmada, quase um século depois, por Antonio Vieira, em 1659, em um relato histórico sobre "os primeiros missionários da Companhia de Jesus que penetraram pelas terras no Maranhão". ${ }^{15}$ Ele conta que, por volta do ano 1605 , 
[...] traziam os padres por ordem que intentassem os sertōes do Maranhão que naquele tempo estava ocupado pelos franceses, apalpando a disposição dos índios seus confederados, e vendo se os podiam inclinar à pureza da fé católica, que entre os franceses estava mui viciada de heresias. ${ }^{16}$

Por sua vez, Vicente do Salvador, do convento franciscano da Bahia, fornece uma imagem quase mítica da heresia francesa, contando que seu predecessor, o frei Cristóvão Severim, chegado ao Maranhão logo após a derrota de 1615, no local da França Equinocial,

[...] queimou muitos livros que achou dos franceses hereges e muitas cartas de tocar e oraçôes supersticiosas que muitos usavam, apartou os amancebados das concubinas, e fez muitas obras do serviço de Nosso Senhor... ${ }^{17}$

Lembremos, entretanto, que a radicalidade desses testemunhos encerra uma dimensão mais política do que moral: a imagem corrente do amálgama cultural franco-tupi, corolário da associação entre o fenômeno de "endotismo" e a heresia difusa nos costumes e na religião dos franceses, é parte integrante de um vasto programa de luta contra o invasor herege. ${ }^{18}$

A penetração dos franceses na inextricável tessitura social indígena era a condição para as alianças com os tupinambá, visando, num primeiro momento, garantir a eficácia das relaçōes comerciais. Mas ela acabou, após vários anos de contato, produzindo uma verdadeira mestiçagem através dos truchements. Das narrativas em língua francesa que descrevem a "acomodação" dos truchements no meio tupinambá e a "mestiçagem" franco-tupi, uma das primeiras é a Histoire d'un voyage, de Jean de Léry, que não se furta a uma descrição radical dos fatos, expondo o risco do triunfo da selvageria sobre os espíritos civilizados.

[...] alguns intérpretes normandos, residentes há vários anos no país, tanto se adaptaram aos costumes bestiais dos selvagens que, vivedo como ateus, não só se poluíam em toda espécie de impudicícias com as mulheres selvagens mas ainda excediam os nativos em desumanidade, vangloriando-se mesmo de haver morto e comido prisioneiros. ${ }^{19}$

Jean de Léry condena severamente a liberdade das relações entre os franceses e as mulheres indígenas. Para ele, essas relações deviam submeter-se a leis humanas, sob pena de dar livre curso ao costume bárbaro. Numa 
passagem de seu relato, Léry se preserva da contradição, e reconhece, apesar de sua divergência radical em relação a Villegaignon, a necessidade da disciplina que este último havia imposto no forte de Coligny.

[certos normandos] haviam ficado entre os selvagens, onde, vivendo amasiados sem temor a Deus, alguns com filhos já de quatro a cinco anos de idade, e a fim de evitar que o mesmo não acontecesse aos de nossa ilha e de nosso fortim, proibiu Villegaignon, depois de ouvir o parecer do conselho, que nenhum cristão se juntasse às mulheres dos selvagens, sob pena de morte $[\ldots] .{ }^{20}$

A condenação moral de Léry do "ensauvagement" dos franceses não o impediu, contudo, de "acomodar-se às praias" ao lado dos índios, de freqüentá-los e de comer e beber entre eles. ${ }^{21}$

Algumas passagens das cartas e dos relatos dos religiosos portugueses concordam, de fato, com o parecer do huguenote sobre o caráter "ateísta" dessas relações. De maneira geral, as críticas denunciam a facilidade com a qual os franceses conseguiam "amancebar-se” com as índias. É bem verdade que, para os missionários da Companhia de Jesus, a reação contra essa "mestiçagem" incontrolável baseava-se no temor de seu caráter não somente herético, mas sobretudo velado.

Não surpreende constatar que a situação no Maranhão, no início do século XVII, estivesse particularmente sujeita a críticas dessa natureza. Foi assim que o jesuíta português Domingues, num relato sobre a entrada feita no Maranhão, em 1613, assinalou a presença de "uma índia que devia ser filha de algum dos 7 franceses, dos quais ali não faltava geração [...]". ${ }^{22}$ Sendo, além disso, acusada de adultério, essa índia meio caatinga meio francesa teve os seus atributos físicos fabulosamente descritos nesse mesmo relato: "diz o informante que a natureza se esmerou em a dotar das partes requisitas para a afeição corporal..." ${ }^{23}$

De Jean de Léry aos religiosos portugueses, essas ligações inconfessáveis não deixaram de inquietar, por diferentes razões, os espíritos cristãos. Com efeito, o problema da normalização das relaçóes logo se fez sentir para a colônia francesa do Maranhão: os costumes indígenas, que se prestavam perfeitamente, havia muito, à licenciosidade voluntária dos mercadores e truchements, deviam ser severamente sancionados sem que, contudo, isso 
trouxesse prejuízo à proximidade e à cordialidade das relações entre a nação francesa e a tupinambá. ${ }^{24}$

É nesse sentido que o capuchinho Yves d'Evreux relata a interdição feita aos membros da companhia francesa de tomar concubinas selvagens.

Os índios costumavam dar suas filhas aos seus compadres, elas logo assumem o nome de Maria e o sobrenome do francês, para designar a aliança com o tal francês, de modo que dizer "Maria de tal", equivalia a dizer a concubina de um tal [...] Esse costume de tomar as filhas dos selvagens foi proibido aos franceses e isso não se faz mais, a não ser veladamente. ${ }^{25}$

O problema é mais complexo do que aparenta. O respeito para com as mulheres indígenas constitui um dos pontos centrais das normas de organização da França Equinocial. A questão aparece explicitamente pela primeira vez no capítulo XXVIII da Histoire de la Mission, no qual o reverendo padre Claude transcreve o documento que contém as "Leis fundamentais decretadas na ilha do Maranhão". Assinado pelos "Lugar-tenentes gerais de Sua Majestade nas Índias Ocidentais", o texto se divide em quatro partes: a primeira assegura "a glória e o serviço de Deus"; a segunda, "a honra ao Rei"; a terceira, "a conservação da companhia”; a quarta e última, é dedicada à "conservação dos índios", a partir de então sob a guarda dos franceses. ${ }^{26}$

Essa quarta parte é fundamentalmente composta por três leis, dentre as quais duas dizem respeito aos contatos dos franceses com as mulheres indígenas, prevendo até mesmo a pena de morte para aqueles que transgredissem as interdiçôes.

ORDENAMOS que não se cometa adultério, por amor ou violência, com as mulheres dos índios, sob pena de morte [...]; igualmente ordenamos, sob idêntica pena, que não se violentem as mulheres solteiras. / ORDENAMOS que se não pratiquem quaisquer atos desonestos com as filhas dos índios [...]. ${ }^{27}$

É evidente que esse conjunto de leis, que visava promover a disciplina necessária à prosperidade da empresa colonial, vinculava-se diretamente à situação gerada por longos anos de contato entre tupinambás e franceses. Concebidas, com toda probabilidade, pelos próprios padres capuchinhos, ${ }^{28}$ essas regras procuravam definir não somente o estatuto dos religiosos no 
âmbito da colônia, como também sua inserção no meio selvagem. Pois, se por um lado elas deviam necessariamente corresponder às normas que regem as relações entre missionários e infiéis, internamente à ordem religiosa, por outro lado eram condicionadas pelas imposiçôes culturais ou históricas que determinavam as relações entre franceses e aliados tupinambás.

Segundo os termos transcritos por Claude d'Abbeville em seu relato, os índios queixavam-se, em 1612, de que os franceses que tinham permanecido no Maranhão para traficar com eles no passado não lhes tivessem ensinado como "adorar e servir a Deus". ${ }^{29}$ Uma vez definitivamente instalada a colônia francesa, uma das primeiras atitudes dos "Profetas" — como eram designados os capuchinhos pelos índios, segundo o Padre Claude foi demarcarem-se da promiscuidade nascida dos primeiros contatos entre selvagens e mercadores ou "truchements ensauvagés". É significativo que o primeiro discurso que o chefe índio Iapy Ouassou (Japiaçu) dirigiu ao padre Yves d'Evreux tenha se baseado no espanto em face de uma nova modalidade de relações, e no profundo desejo de conhecer-lhe as razões.

Mas admira-me muito que vós outros Paí não desejeis mulheres. Descestes do céu? Nascestes de pai e de mãe? Como pode ser! Não sois homens como nós? E por que, além de não quererdes mulheres, ao contrário dos outros franceses que conosco negociam há quarenta e tantos anos, vós agora ainda impedis de que os vossos companheiros usem de nossas filhas (o que reputamos grande honra, porquanto deles podem ter filhos)? ${ }^{30}$

Ultrapassando o contexto estrito das normas que regem a atividade missionária, a referência quase obsessiva, no corpus de obras capuchinho, à questão do respeito para com as mulheres indígenas está diretamente vinculada à política colonial francesa, calcada no sistema das alianças comerciais. É, particularmente, o relato do capuchinho Yves d'Evreux, a Suite de l'Histoire des choses mémorables, que fornece a chave de compreensão da modalidade de relaçôes humanas estabelecida pela prática do escambo.

Depois do percurso das "singularidades" ${ }_{1}$ naturais e humanas do Maranhão, três capítulos encerram o primeiro tratado do livro do Padre Yves. Eles constituem, de fato, um verdadeiro "guia do viajante" da França Equinocial, visando encorajar novos comanditários bem como eventuais participantes de uma provável segunda expedição. O capítulo XLVIII, que 
contém um diálogo fictício entre um francês e um conhecedor da região (que ocorre ser o próprio narrador, o padre Yves), fornece, em tom muito exaltado, as "respostas a várias perguntas que em nossos países se fazem sobre as Índias Ocidentais". ${ }^{32} \mathrm{O}$ texto procura eliminar qualquer inquietação quanto à possibilidade de adaptação dos franceses às condições de vida (moradia, alimentação, salubridade etc.) no Maranhão. Dirigindo-se, enfim, à “infinidade de jovens fidalgos que nada têm a perder senão a espada e o punhal", ${ }^{33}$ Yves d'Evreux encoraja-os a embarcar, antes de enunciar, à guisa de conclusão, uma frase que lembra muito as fórmulas de nossas campanhas publicitárias: "Além de um passatempo, isso vos traria paz de espírito e vigor ao juízo; prestaríeis serviço a Deus e ao vosso rei visitando aquela Nova França". ${ }^{34}$

Essas últimas linhas introduzem o tema central, cuidadosamente apresentado pelo capuchinho como uma resposta à pergunta feita pelo francês: "se isso for verdade [boas condições de vida], nada mal, mas pode-se tirar disso algum proveito?"35 A resposta é clara, a região é, sem dúvida, rica em recursos exploráveis e potencialmente propícia à produção de numerosas mercadorias inventariadas no texto. ${ }^{36}$ Yves d'Evreux mostra de que modo as leis intrínsecas do escambo são baseadas no respeito ao "natural indígena” para então avançar um argumento espiritual e uma crítica aos modos de vida europeus. Explica como os selvagens, ao verem as poucas mercadorias trazidas pelos franceses, ${ }^{37}$ tornaram-se preguiçosos:

Eles nada quiseram fazer e nada farão enquanto os franceses nada tiverem a oferecer-lhes em recompensa, pois tal é o seu natural... Não são reprováveis por isso, já que em toda cristandade não encontrareis um só homem que deseje trabalhar de graça. ${ }^{38}$

Completando as instruçóes necessárias a qualquer viajante desejoso de tentar a vida nessas paragens, o capítulo seguinte constitui um verdadeiro "manual do escambo". Todo sucesso da empreitada consistia, segundo Yves d'Evreux, em munir-se de duas espécies de provisões: uma para si próprio, a outra para os selvagens, a fim de obter deles víveres e mercadorias. ${ }^{39}$ Toda a lógica ritual do escambo é desvelada, e facilmente se compreende que a política de bom entendimento com os tupinambás praticada pelos franceses devia implicar, igualmente, relações sociais específicas. 
Uma vez acolhido no porto pelo selvagem que passará a ser seu compadre e que o acolherá na sua família, o viajante deve seguir os seus conselhos: "Não vos deixeis levar — diz Yves d'Evreux — pelos trejeitos graciosos das filhas de vosso anfitrião, ou dos outros: elas não cessarão de adular-vos se souberem que possuís mercadorias [...]" ${ }^{40}$

No último capítulo, que encerra o tratado, intitulado "Da recepção que fazem os selvagens aos franceses recém-chegados e como comportarse para com eles", o interlocutor fictício entrega-se à evidência da inabalável amizade franco-tupi. Yves d'Evreux assinala-lhe, em termos não menos apologéticos, as suas características mais sutis.

Se há nação no mundo voltada à boa acolhida de seus amigos recém-chegados, à acomodação destes nas casas para dar-lhes o melhor tratamento possível, é aos tupinambá, em sua relação com os franceses, que cabe o primeiro lugar $[\ldots] .{ }^{41}$

A voz de um selvagem hipotético dramatiza o que está em jogo num primeiro contato ideal com um francês recém-desembarcado. Essa encenação exemplar resume, por antecipação, o desenrolar quase ritual dos eventos e dá, ao mesmo tempo, o tom do comportamento suposto ser conveniente para o francês na ocasião do encontro.

Eis que chegam os navios de França, pensa o selvagem, hei de ser bom compadre: ele me dará machadinhas, foices, facas, espadas e vestimenta; eu lhe darei minha filha, caçarei e pescarei para ele, farei muito algodão, procurarei plumas de garça e âmbar para dar-lhe [...]. ${ }^{42}$

Assim, página após página, o reverendo padre Yves fornece as chaves da compreensão - o relato dos costumes indígenas e a tradução das perguntas feitas em tupi - de um primeiro diálogo-modelo. ${ }^{43}$ Esse primeiro tratado termina com o repouso de um viajante cansado: "Erei potar touroumi? Tens fome de sono? Queres dormir?”, pergunta o selvagem, sugerindo, através dessa imagem, a confiança que o francês deve depositar no seu anfitrião.

Foram essas relações, inerentes à prática do escambo, que tornaram possível o emprego pelos franceses de uma mão-de-obra benévola para o carregamento dos navios. Um comércio da amplitude do de pau-brasil te- 
ria sido, com efeito, impraticável sem a cooperação sistemática dos índios. Uma vigilância escrupulosa era certamente necessária para assegurar que as árvores fossem abatidas no melhor momento do ano, pois era na lua nova (durante a estação das chuvas) ou no último quarto de lua (durante a estação seca) que o famoso "bois de braise" se encontrava em seu mais alto teor de tintura. Em seguida, era preciso contar com a mão-de-obra indígena para cortar aquelas enormes árvores em toras de um a dois metros, tirar-lhes a casca e transportá-las, inicialmente nas costas, em seguida em carroças, até uma praia, antes de carregar o navio que levaria a carga para a Europa. ${ }^{44}$

A precocidade e a importância do tráfico de pau-brasil, comandadas pela crescente demanda da tintura vermelha pelo mercado têxtil em expansão na Europa, fizeram do comércio franco-brasileiro a principal empresa colonial francesa no Novo Mundo durante o século XVI. ${ }^{45}$ Essa "experiência brasileira" contribuiu fortemente para a formação de um modelo de relação comercial que esteve igualmente em uso no Canadá, onde logrou assegurar a predominância dos franceses no tráfico de peles enquanto permaneceram no norte do continente. ${ }^{46}$ As técnicas do escambo de peles, baseadas no ritual de troca de presentes, faziam parte de uma política de mesma natureza que aquela praticada com os tupinambá, ainda que, naquela parte da costa americana, as relações não obedecessem necessariamente à uma lógica de rivalidades nacionais e de alianças belicosas.

Representando as relações franco-tupi sob o signo do bom entendimento desde, pelo menos, a segunda metade do século XVI, os cronistas franceses abriram o caminho a uma discussão sobre a possível formação de um império colonial no Brasil. Um dos primeiros episódios que transmitem uma idéia da importância sociopolítica dessas relações é a cerimônia da entrada real de Henrique II em Rouen, em 1550. Três livretos, publicados sucessivamente em 1550, 1551 e 1557 ilustram, através de uma gravura sobre madeira, a "Festa Brasileira", que simulava a vida selvagem nas florestas tropicais, com a presença de cerca de 50 índios trazidos para a cerimônia, ao lado de marinheiros fantasiados "à la tupinambá". ${ }^{47} \mathrm{O}$ texto que acompanha a edição de 1551 fornece uma descrição detalhada do tráfico do pau-brasil "que os marinheiros deste país costumam fazer quando tratam com os brasileiros", ${ }^{48}$ e indica a terminologia indígena para as di- 
versas espécies de pássaros coloridos, muito procuradas pelo mercado francês da época. Os armadores de Rouen possuíam um objetivo preciso ao apresentar esse espetáculo: atrair a atenção do rei para as riquezas do país e levar, se possível, a França a ingressar numa política de exploração comercial dessa madeira corante. ${ }^{49}$

A importância da difusão da Figure des Brisilians no interior dos livretos da entrada real - objeto impresso que foge ao estrito âmbito do que se convenciona chamar "literatura de viagens" do século XVI — foi, talvez, maior do que se possa imaginar. Um exemplo eloqüente se encontra na carta náutica, concebida mais de meio século depois, por Pierre de Vaulx. ${ }^{50}$ Sobre o território brasileiro, encontram-se as inscriçôes "Brasil" e, à altura do nordeste, "França Antártica". É improvável, todavia, que o cartógrafo estivesse fazendo referência à colônia de Villegaignon, episódio notoriamente encerrado havia 53 anos. Em contrapartida, parece plausível que a presença francesa no norte do país estivesse simbolizada por esse título corrente, uma vez que o de "França Equinocial" não fora popularizado senão a partir dos eventos que marcaram a passagem dos tupinambá por Paris e a publicação do relato de Claude d'Abbeville, no início de 1614. Além disso, as dimensões da "Rivière des Amazones" aparecem ampliadas nessa carta, desde sua desembocadura, nas proximidades de "Maragnan" (igualmente inscrito na carta) até o "Peru", no extremo oeste do continente, fazendo sobressair uma região acessível aos mercadores franceses, e já muito conhecida pelos pilotos normandos e bretôes. ${ }^{51}$ Mas causam surpresa, na carta, as ilustrações dos costumes indígenas, distribuídas por todo o continente, nitidamente calcadas nas imagens da Figure des Brisiliens dos livretos da entrada real. ${ }^{52}$

Indiscutivelmente, a continuidade que se faz sentir, depois da segunda metade do século XVI, no elogio das relaçóes de amizade franco-tupi - que vai desde as representaçóes veiculadas pela entrada real de 1550, passando pelo relato de Jean de Léry até os dos capuchinhos - é sinal de que a economia do escambo no Brasil se manteve duravelmente pelo menos até o início do século XVII. ${ }^{53}$ Fiéis a uma verdadeira tradição de relações, os cronistas franceses, de maneira geral, mencionaram regularmente os gestos de cordialidade dos mercadores e truchements para com os tupinambás nas costas brasileiras. 
É preciso também reconhecer a dimensão estratégica da atitude dos capuchinhos, nas primeiras décadas do século XVII, que procuraram recuperar o modelo já estabelecido da relação com os índios — em nome da manutenção de um modelo econômico, e em proveito de uma atitude que pode ser julgada, a posteriori, pré-etnográfica — anterior à Etnografia. ${ }^{54} \mathrm{~A}$ missão dos capuchinhos no Maranhão foi, sem dúvida, marcada pelas imposições desse modelo econômico e, ainda mais, pela herança cultural das relações franco-tupi. ${ }^{55}$

O apostolado dos capuchinhos no Maranhão se situaria, então, na junção de um projeto evangelizador e das ambições político-coloniais específicas da França no Brasil. Claude d'Abbeville tentou escrever uma narrativa modelo, ao mesmo tempo verdadeiro tratado sobre os tupinambás e obra edificante do ponto de vista missiológico. Yves d'Evreux, por sua vez, procurou dar, na sua narrativa "programática", a medida exata de um projeto colonial e missionário promissor. Em ambos os casos, é forte a inclinação para celebrar a inocência do selvagem, ao ponto de inserir o canibalismo tupinambá no âmbito ritual, como "erro hereditário oriundo do ritual de vingança" ${ }^{56}$ Resta saber em que, precisamente, a atitude dos capuchinhos é original, e identificar o que a aproxima, por exemplo, da do huguenote Jean de Léry. ${ }^{57}$

Muito já foi dito quanto às visões diferenciadas da alteridade indígena por parte de franceses e portugueses, viajantes e missionários. A tese corrente de uma divisão no interior da "literatura" sobre o Brasil — de um lado, a visão do colonizador português que deprecia a imagem do índio e, de outro, a do viajante francês que o exalta - é, no entanto, de extrema simplicidade. ${ }^{58}$ Ela não pode dar conta das clivagens no interior das ideologias religiosas dos séculos XVI e XVII, nas quais se acham inseridas as visões de viajantes, colonizadores e missionários, e nem da lógica de formação e de circulação de um capital de informação sobre os índios brasileiros.

É preciso que sejam ressaltadas as ambições francamente colonialistas de empresas como a França Equinocial. Elas distinguem-se, evidentemente, das motivações que fundamentam o modelo de colonização lusitano, mas encontram-se também profundamente implicadas, no interior do 
modelo político-econômico francês, com os aspectos de ordem política, ética e teológica que marcam a conquista americana. Assim, a atitude de tolerância e de respeito à integridade física e moral do índio, manifesta nos relatos dos missionários capuchinhos ou no de Jean de Léry, não deve ser forçosamente identificável à dos viajantes franceses de um modo geral, e muito menos comparável, por antítese, à dos missionários portugueses. ${ }^{59}$

Os capuchinhos não foram vítimas dos efeitos perversos do fenômeno de "endotismo" dos franceses no Brasil. Antes, adaptaram lucidamente o seu apostolado a uma realidade natural e humana, cujos códigos relacionais haviam sido previamente estabelecidos. Eis porque, para além de qualquer particularidade confessional ou nacional, os missionários do Maranhão, Claude d'Abbeville e Yves d'Évreux, tiveram uma visão do índio raramente encontrada entre os seus contemporâneos.

\section{0 mito do selvagem convertível}

Uma questão que permite estabelecer as bases dessas visões diferenciadas do índio brasileiro nos relatos produzidos nos primeiros séculos da conquista portuguesa, é, sem dúvida, a da origem dos índios do Brasil, corolária à da sua conversibilidade.

A escolha da hipótese camita como resposta à questão da origem do índio não obteve a adesão exclusiva dos jesuítas portugueses, a exemplo de Manuel da Nóbrega, que no seu Diálogo sobre a conversão do gentio apresenta o tupinambá como descendente legítimo de Cam e portador de sua maldição. ${ }^{60} \mathrm{Na}$ segunda metade do século XVI, na França, ela foi exaltada pelo calvinista Jean de Léry, que no capítulo XVI de sua Histoire d'un voyage, dedicado à religião dos tupinambás, ${ }^{61}$ enuncia os fundamentos da teoria de sua origem maldita:

No que concerne à beatitude eterna em que cremos [...] são os selvagens um povo maldito e desamparado de Deus, não obstante as noções muito imperfeitas que possuem da vida [...]. Parece-me pois mais provalvel que descendam de Cam. [...] É verossímil que os avós e antepassados de nossos americanos, expulsos de Canaan pelos filhos de Israel, tivessem embarcado e se deixado levar ao léu até aportar em terras da América. ${ }^{62}$ 
No interior do calvinismo mais doutrinário, a conjetura de Léry sobre a origem camita dos tupinambá compromete radicalmente a sua conversão. Em Histoire d'un voyage, o relato do fracasso da França Antártica, em meio a um discurso francamente anticolonialista, vem ratificar o pessimismo dogmático de Léry, que vê os índios como "objeto de uma maldição particular que se adiciona à do pecado original, comum a todos os homens". ${ }^{63}$

Meio século depois, Claude d'Abbeville omitiu-se em seu relato quanto à questão da origem dos índios que encontrou no Maranhão. A idéia da descendência camita dos tupinambás, e por conseqüência a da sua inconversibilidade, eliminava, de saída, toda possibilidade de evangelização e condenava todo projeto de colonização ao paradoxo ou à violência - tal qual era praticada, segundo o padre Claude, por portugueses na América.

Assim, desprezando a dimensão teológica da origem destes homens "banidos e exilados do Ocidente", ${ }^{64}$ é através do relato histórico da migração das tribos tupi para o norte, fugindo à perseguição dos peros [portugueses], que o capuchinho avança o argumento do encontro providencial dos missionários franceses e das almas pagãs dos tupinambá. ${ }^{65}$

O posicionamento radical de Jean de Léry em relação à religião dos selvagens — os quais diz ele ter freqüentado "familiarmente" durante um ano $^{66}$ — parece ser incompatível com a imagem do bom tupinambá que seu livro não cessa de veicular. ${ }^{67} \mathrm{~A}$ atitude de respeito à diferença e de tolerância em relação aos índios no relato de Claude d'Abbeville encerra a mesma dimensão inovadora que a de Jean de Léry, mas afasta-se, de saída, do pessimismo do huguenote quanto às possibilidades de conversão.

Para construir a imagem de um tupinambá bom, e ao mesmo tempo para poder calar-se quanto à questão de suas origens, o padre Claude dá um caráter de predestinação à nova aliança franco-tupi, e de urgência à ação misionária e à colonização. A "nação tupinambá", "privada não somente da bela luz e do conhecimento deste grande Tupã, mas também da conversação dos franceses", ${ }^{68}$ durante o tempo das perseguições dos peros, tornava-se, assim, objeto da compaixão do rei de França, que havia enviado homens bravos e bons missionários para a proteção dos corpos, dos bens e das famílias indígenas. 
Nesses termos discursam, respectivamente, o chefe Iapy Ouassou e François de Razilly:

[...] tenho grandes esperanças em tua bondade e em tua brandura [douceur], pois parece-me que em teus modos guerreiros há uma maneira amável, própria a uma personagem que nos governará com sabedoria; e te direi a esse propósito que quanto mais um homem é grande de nascença e quanto maior autoridade tem sobre os outros, mais brando, obsequioso e clemente deve ser. Pois os homens, especialmente os desta nação, mais facilmente se levam pela brandura do que pela violência. ${ }^{69}$

Não foram nem a beleza nem as riquezas de tua terra que aqui me conduziram [...]. Foi apenas o desejo que tenho de ver vossas almas, depois de vossa vida, preservadas da danação eterna, e dos tormentos de Jurupari [...]. Foi também o desejo de salvar de vossos inimigos os vossos corpos, os vossos bens e as vossas famílias. Eis os dois motivos que me levaram a vos procurar. ${ }^{70}$

A idéia da predestinação do encontro entre tupinambás e franceses é manifesta, por um lado, na vocação missionária da França, filha mais velha da Igreja, e por outro, no tema da inocência do paganismo indígena, abordado no prefácio da Histoire de la Mission. Claude d'Abbeville alia, estrategicamente, esta predestinação a uma suposta lusofobia indígena, notadamente na transcrição dos discursos dos chefes tupinambás, como o de Iapy Ouassou dirigido a François de Razilly: "Estou muito contente, valente guerreiro, com o fato de teres vindo a esta terra para fazeres a nossa felicidade e nos defenderes contra os nossos inimigos. Já começávamos a nos aborrecer por não vermos chegar os guerreiros". ${ }^{71}$

Dando a palavra ao índio, Claude d'Abbeville faz com que seja revelada a suposta expressão da compatibilidade entre a doçura indígena e a predicação doce dos capuchinhos franceses. Iapy Ouassou declara em público: "Quanto a mim, sempre pratiquei essa máxima com aqueles que tive sob meu comando e sempre me dei bem. Sempre observei também essa brandura [douceur] entre os franceses, pois, se não os tivéssemos achado bons, teríamos afundado nas matas, onde ninguém nos poderia seguir..." ${ }^{72}$

Nesse sentido, se o padre Claude d'Abbeville se cala sobre a dimensão teológica da origem dos tupinambás, ele se posiciona lado a lado com Jean de Léry no que diz respeito à exaltação da sua bondade. No relato de Léry, a denúncia da incoerência do projeto colonial de 1555 fica muito aquém 
da imagem que constrói do bom tupinambá, implicitamente travestido em huguenote massacrado. ${ }^{73}$ Parece, portanto, possível que a mensagem de Jean de Léry tenha podido servir aos interesses mais contraditórios, meio século mais tarde, até mesmo a uma certa lusofobia e à apologia do selvagem contidas nas obras dos capuchinhos do Maranhão. ${ }^{74}$ Claude d'Abbeville se permite, até mesmo - no momento em que o sucesso editorial de Jean de Léry atinge seu último pico - , parafrasear o relato da viagem do huguenote ao Rio de Janeiro. ${ }^{75}$

Contrariando a sentença de Cícero, os tupinambás de Léry são representados na Histoire d'un voyage como um povo selvagem e bárbaro, ignorante de todo e qualquer sentimento de divindade:

Embora seja aceita universalmente a sentença de Cícero, de que não há povo, por mais bruto, bárbaro ou selvagem que não tenha idéia da existência de Deus, quando considero os nossos tupinambás vejo-me algo embaraçado em lhe dar razão. Pois [...] não adoram nenhuma quaisquer divindades terrestres ou celestes $[. .$.$] não oram em público nem em particular [...] não$ distinguem os dias por nomes específicos, nem contam semanas, mesese anos, apenas calculando ou assinalando o tempo por luas. ${ }^{76}$

Claude d'Abbeville, que privou o tupinambá da maldição camita, se exprime, no entanto, nos mesmos termos de seu predecessor huguenote quanto à religião dos selvagens:

Não há, penso eu, nenhuma nação no mundo que não tenha uma religião. Todas adoram um deus, salvo a dos tupinambás que não adora nenhum, nem celeste nem terrestre [...] Nunca souberam os índios tupinambás o que fosse nem prece, nem ofício divino, nem oração pública ou particular. Contam as luas, mas não distinguem as semanas, nem os dias de festa, nem os domingos. ${ }^{77}$

Mesmo discordando quanto à questão da convertibilidade dos selvagens, Claude d'Abbeville reitera a imagem construída por Jean de Léry, quase meio século antes, de um povo bárbaro, ignorante de Deus e dos valores religiosos ocidentais. Mas é sobretudo no que diz respeito ao "natural tupinambá" que a paráfrase do padre Claude se torna significativa. ${ }^{78} \mathrm{~A}$ análise da vida doméstica familiar da sociedade indígena, no relato 
do capuchinho, é claramente tirada do texto do huguenote. Por exemplo, em relação aos cuidados administrados aos recém-nascidos, diz Claude d'Abbeville:

Quanto aos filhos, apenas nascem, os pais os friccionam com óleos e tinturas, como já foi dito, e deitam-nos em redezinhas de algodão, sem enfaixálos nem cobri-los. Creio que por isso mesmo são menos sujeitos do que os nossos a se tornar corcundas ou contrafeitos; pois entre nós, desde o nascimento, são as crianças enfiadas em berços e metidas dentro de vestimentas tão apertadas que violentam a natureza, a ponto de somente com dificuldade poderem crescer. Daí a grande quantidade de indivíduos tortos, coxos e corcundas. $\mathrm{O}$ mesmo não ocorre com os índios que deixam a natureza expandir-se em liberdade. E agrada ver as crianças, de quatro, cinco e seis anos... ${ }^{79}$

Sobre o mesmo assunto, Jean de Léry dizia sobre os tupinambás do Rio de Janeiro:

Apenas sai do ventre materno, é o menino bem lavado e pintado de preto e vermelho pelo pai, o qual, sem enfaixá-lo, deita-o em uma rede de algodão [...] Voltando ao assunto, cumpre-me observar que na Europa consideramos, em geral, que se as crianças não forem bem apertadas em sua primeira infância, e bem enfaixadas, terão pernas tortas ou ficarão aleijadas. Isso não se verifica em aboluto com os filhos dos nossos americanos. [...] no verão e nas estações temperadas parece, pela experiência que tenho, que melhor seria deixar espernearem à vontade em leitos de que não pudessem sair. Com efeito, creio que muito prejudica a essas pequenas e tenras criaturas ficarem constantemente aquecidas e semi-assadas nesses cueiros que servem tanto no inverno como no verão. ${ }^{80}$

A utilização da trama narrativa e da tópica moral de Jean de Léry pelo padre Claude ${ }^{81}$ não se restringe à observação da sociedade tupinambá. Seguindo os topoi de uma escrita "etnológica", ela engloba também a crítica à sociedade européia, como pode-se constatar a partir das páginas célebres sobre a nudez das índias, que o capuchinho também tomou de empréstimo ao calvinista.

Pensam muitos ser coisa detestável ver esse povo nu, e perigoso viver entre as índias, porquanto a nudez da mulheres e raparigas [...] porém o perigo é 
mais aparente do que real, e bem menos perigoso é ver a nudez das índias do que os atrativos lúbricos da mundanas de França. [...] essa nudez não é em si tão perigosa nem tão atraente, ao contrário dos requebros, lubricidades e invençōes das mulheres de nossa terra $\left[\ldots . .{ }^{82}\right.$

Frente à nudez das índias, Jean de Léry havia escrito:

[...] quero responder aos que dizem que a convivência com esses selvagens nus, principalmente entre as mulheres, incita à lascívia e à luxúria [...]. a nudez grosseira das mulheres é muito menos atraente do que comumente imaginam. Os atavios, arrebiques, postiços, cabelos encrespados, golas de rendas, anquinhas, sobre-saias, e outras bagatelas com que as mulheres de cá se enfeitam e de que jamais se fartam, são causas de males incomparavelmente maiores do que a nudez habitual das índias. ${ }^{83}$

O quadro das "singularidades" humanas na Histoire de la Mission é inaugurado logo após os capítulos dedicados às "singularidades" naturais da ilha de Maragnan. Mas Claude d'Abbeville teria dificilmente podido reunir, nos quatro meses em que permaneceu no Maranhão, todas as informações sobre os tupinambás que fornece nessas páginas. É provável que o projeto de escrita da Histoire de la Mission seja anterior ao retorno do padre Claude a Paris, e que ele tenha tido informantes e intérpretes - como o próprio Migan - à sua disposição em permanência. Durante a travessia de retorno à Europa, os meses que separam as cerimônias parisienses com os embaixadores tupinambá e a impressão do livro, Claude d'Abbeville teria tido condiçôes de organizar suas notas e redigir seu texto. ${ }^{84}$

Isso poderia não somente justificar o parentesco entre os dois textos, mas sobretudo indicar a lógica de seleção das passagens parafraseadas. Uma vez que, nos primeiros anos do século XVII, o sucesso do bom tupinambá de Léry parecia já irrevogável, e que em termos do que convencionamos chamar "literatura de viagens" o capital de informações estava sempre sujeito à pilhagem, Claude d'Abbeville permitiu-se tomar de empréstimo a Léry muito mais do que informações sobre os índios brasileiros que encontrou rapidamente: tomou de empréstimo, principalmente, a postura do calvinista e a idealização daqueles que observava, advinda talvez da própria construção "literária". ${ }^{85}$ 
Por mais que a Histoire de la Mission pretenda ser uma narrativa "histórica” do estabelecimento da colônia francesa, a escrita do padre Claude é, antes de tudo, missionária, e busca dar conta dos batismos, das conversões e das curas milagrosas ocorridas no Maranhão. Investido, acima de tudo, de sua missão, Claude d'Abbeville não pôde "freqüentar familiarmente" os índios do Brasil como Jean de Léry, este sim, exilado, na condição de sobrevivente dentre os canibais.

Portanto, no que diz respeito aos detalhes sobre os usos e costumes dos tupinambá, a escrita do capuchinho deve muito à do huguenote. $\mathrm{O}$ elogio que faz Jean de Léry à compleição física dos índios de par-delà, sempre aliada à crítica dos homens de par-deçà, ${ }^{86}$ abre espaço mais uma vez à paráfrase. Segundo Léry:

[...] os selvagens do Brasil, habitantes da América [...] não são maiores nem mais gordos do que os europeus; são porém mais fortes, mais robustos, mais entroncados, mais bem dispostos e menos sujeitos a moléstias, havendo entre eles muito poucos coxos, disformes, aleijados ou doentios. Apesar de chegarem muitos a cento e vinte anos [...] poucos são os que na velhice têm os cabelos brancos ou grisalhos, o que demonstra não só o bom clima da terra [...] mas ainda que pouco se preocupam com as coisas deste mundo. E de fato nem bebem eles nessas fontes lodosas e pestilenciais que nos corroem os ossos, dessoram a medula, debilitam o corpo e consomem o espírito, em suma que [na Europa] nos envenenam e matam e que são a desconfiança e a avareza, os processos e intrigas, a inveja e a ambição. Nada disso tudo os inquieta e menos ainda os apaixona e domina $\left[\ldots . .{ }^{87}\right.$

E o padre Claude constata sobre "a estatura e a longevidade dos índios tupinambá do país de Maranhão":

Os índios tupinambá [...] todos naturalmente bem feitos e proporcionados, em parte graças ao clima temperado do país e em parte por não viverem constrangidos em suas roupas como aos nossos elegantes acontece. [...] Não há entre eles nenhum zarolho, nem cegos, corcundas, coxos ou disformes;[...] São admiravelmente sadios, bem dispostos e muito mais robustos do que os nossos homens mais robustos. [...] não são valetudinários, nem doentes [...] Não observamos inúmeras moléstias nascerem da cólera, da tristeza, do medo e de outros sentimentos em estado de exaltação? E quantas enfermidades não têm sua causa no ar corrompido ou intemperado, na má nutrição ou, 
ao contrário, na excessiva fartura, ou ainda no abuso do vinho? [...] No Maranhão, entretanto, são muito menos do que entre nós sujeitos a tais enfermidades, [...] são, ao contrário, muito fortes, bem dispostos, [...] Tão saudável é o clima, que só morrem de velhice, de fraqueza natural e não de moléstias. E vivem em geral de cem a cento e quarenta anos [...]. ${ }^{88}$

Ao parafrasear Léry, Claude d'Abbeville buscava talvez garantir uma maior difusão ao seu livro, e até mesmo um certo controle de sua recepção, no horizonte de expectativa dos leitores da Histoire d'un voyage. Além do mais, as condições apressadas de publicação da Histoire de la Mission, num contexto de "propaganda" da colonização do Maranhão e no ambiente solene da recepção e do batismo dos embaixadores tupinambá em Paris, poderiam explicar também, em grande parte, o parentesco entre os dois relatos. ${ }^{89}$

Mas a paráfrase da Histoire d'un voyage indica, antes de tudo, a intenção, por parte do padre Claude, de construir uma imagem do bom tupinambá que fosse compatível com a idéia do respeito ao índio e da salvaguarda de sua integridade física e moral. O bom tupinambá do padre Claude, embora convertível, é claramente tributário daquele inventado por Léry.

Em suma, o parentesco entre os quadros das "singularidades" humanas da Histoire d'un voyage e da Histoire de la Mission sugere que o capuchinho tenha assumido uma postura pré-etnográfica próxima à do huguenote, para fazer triunfar o índio no seu relato. Paradoxalmente, Claude d'Abbeville acabou por se apropriar da imagem do bom tupinambá de Léry, sem efetuar a ruptura que autorizara a postura particular do calvinista: ao separar os índios da natureza e ao excluí-los da remissão, Léry se liberara das preocupações morais e religiosas que o impediam de ver o outro. ${ }^{90}$ Por sua vez, a paráfrase católica do texto do huguenote, cuidadosamente inserida na dispositio do relato missionário, permitiu ao padre Claude mostrar o tupinambá com objeto de análise, sem excluí-lo, contudo, da possibilidade de salvação. O capuchinho se permitiu também este papel de "etnógrafo", abandonando seu dever de proselitismo, uma vez que, longe do compromisso polêmico da obra de Léry, o objetivo de sua obra - e não o seu sucesso - encontrava-se assegurado pelo seu próprio contexto político e editorial. 
Uma vez demonstrada a convertibilidade dos tupinambá no relato de Claude d'Abbeville, o quadro das "singularidades" indígenas, permeado pela crítica à sociedade européia, fornece também elementos para a apologia da colonização. O sucesso editorial do livro de Jean de Léry não havia deixado dúvidas quanto ao fato de que o problema da legitimidade da colonização francesa da América devia ser resolvido, antes de mais nada, pelos discursos impressos. Em 1614 também ele dependerá da escrita do capuchinho, e estará contraditoriamente ligado à definição do "natural tupinambá", que Jean de Léry já havia solidamente legado.

A compatibilidade entre postura pré-etnográfica e colonização em Claude d'Abbeville torna-se cada vez mais evidente: a urgência do projeto missionário brasileiro, expressa, entre outros, na dimensão pública das manifestações populares e na publicação, na França, das cartas e relatos dos missionários franceses enviados ao Brasil, exigiram do "historiador" da França Equinocial uma postura frente ao índio que constituísse uma garantia de sua convertibilidade.

Sem dúvida, a escrita de Jean de Léry não é menos política do que a dos missionários franceses do Maranhão. Mas funcionou no sentido inverso, uma vez que a Histoire d'un voyage é, como se sabe, um manifesto anticolonialista contra a tirania de Villegaignon e as crueldades da colonização luso-espanhola. ${ }^{91}$ Por mais que o selvagem de Léry fosse inconvertível, foi a sua bondade que serviu ao huguenote como argumento básico à crítica da política colonial francesa: para além dos ataques à Villegaignon, a apologia do selvagem possibilitou Jean de Léry condenar radicalmente todo e qualquer projeto evangélico e colonial na América. ${ }^{92}$

Mas, huguenote e missionário capuchinho, ambos deviam pensar a morte do tupinambá. O "pessimismo histórico" de Léry fez com que temesse, para além da questão da salvação, o fim apocalíptico do mundo com a conquista do Novo Mundo. ${ }^{93}$ No oposto, o otimismo do conversor Claude d'Abbeville fez do problema da morte e da salvação - que, evidentemente, os índios ignoravam até então - o leitmotiv de sua obra: salvar as almas pela conversão e salvaguardar os corpos pela ocupação militar.

O entusiasmo contido no relato do padre Claude advém em grande parte, como se pode suspeitar, do próprio élan missionário, que faz do 
miserável irmão par-deçà um índio par-delà, segundo a fórmula expressa pelo próprio capuchinho, ao final de suas cartas enviadas do Maranhão à França: "Claude d'Abbeville, capuchinho indigno e indígena no momento" ${ }^{94}$

Aliás, se em Jean de Léry há uma relação de identificação entre o huguenote perseguido e o selvagem danado, em Claude d'Abbeville o próprio tupinambá convertível parece também representar, muitas vezes, o herético europeu que motivou o avanço da ordem missionária dos Frades Menores Capuchinhos nas províncias francesas. Nesse sentido, a coerência interna e o sentido de totalização do livro do padre Claude demonstram sua intenção de tornar legível aos leitores europeus a trajetória triunfante que vai do selvagem canibal par-delà ao tupinambá afrancesado par-deçà. ${ }^{95}$ Este aspecto é patente nas representações iconográficas dos embaixadores tupinambá no interior do livro de Claude d'Abbeville, onde aparecem vestidos à francesa, constando, em legenda, seus novos nomes de batismo. A estas imagens vêm se somar duas estampas, em forma de affiches, que circularam em Paris entre 1613 e 1614, representando, a primeira, a "postura” dos tupinambá dançando, e a segunda, a cerimônia do seu batismo solene na Igreja dos Capuchinhos.

Para além de uma apologia à convertibilidade dos tupinambás, a Histoire de la Mission é uma apologia à obra missionária capuchinha de alémmar. No interior da pastoral - dita a posteriori barroca - Claude d'Abbeville parece otimizar, e até mesmo dramatizar as competências dos missionários franceses, plenificados pelo aspecto de cordialidade das relações fanco-tupis e pelo desejo de cristianização dos próprios índios. O drama de sua conversão, que se termina em gran finale em Paris, é ao mesmo tempo promessa e garantia aos investidores, ao público cristão e aos representantes da monarquia francesa, de um futuro colonial no Brasil que, sabemos, jamais viria a existir. ${ }^{96}$

Os capuchinos franceses do Maranhão foram, assim, tributários da atitude de autópsia da "realidade indígena" e de idealização do índio, fundadora da escrita "etnológica" de Jean de Léry; detentores da herança cultural das relações franco-tupi, estreitamente relacionada ao projeto colonial francês aplicado ao Brasil; e, não menos, representantes das tendências da teologia missionária que proclamava o uso exclusivo da "persuasão doce". 
O relato de Claude d'Abbeville, assim como o do seu correligionário Yves d'Evreux, se inserem num movimento, inaugurado nas últimas décadas do século XVI, que contribuiu para a construção do mito do tupinambá convertível. Foi este mito que preparou e, em alguns casos, prefigurou o mito da bondade original do selvagem.

\section{Notas}

${ }^{1}$ Acerca dos fracassos da França Antártica de Villegaignon e dos empreendimentos liderados na Flórida pelos capitães huguenotes Jean Ribault e René Laudonnière, vide Frank Lestringant. Le Huguenot et le Sauvage. Paris: Aux Amateurs de Livres, 1990, pp. 21 a 31.

${ }^{2}$ A expressão, aplicada à França Antártica, é de Henri Lancelot de La Popelinière, Les Trois Mondes. Paris: Pierre Huilier, 1582, III, p. 4.

${ }^{3}$ [...] A La Rochelle, Pour Antoine Chuppin. M.D.LXXVIII. Segunda edição por Antoine Chuppin, em Genebra, 1580. Em 1585, o livro obtém uma edição ampliada, ainda em Genebra, pelo mesmo editor. A primeira edição latina do relato é de 1586 (em Genebra, por Eustache Vignon), antes de sua inserção em 1592 na Collection des Grands Voyages de Théodore de Bry (America Tertia Pars Memorabile provinciae Brasiliae Historiam.., Francfort, Theodore de Bry, 1592). Outras ediçôes se seguem: uma edição latina em Genebra, por E. Vignon, em 1594; a quarta edição francesa surge ainda em Genebra, pelos herdeiros de E. Vignon, em 1599 (seguida de outra datada de 1600); e a quinta e última edição francesa, dedicada à Princesa de Orange, é editada por Jean Vignon, em Genebra, em 1611. Citaremos aqui a tradução brasileira de Sérgio Milliet (Viagem à terra do Brasil. Belo Horizonte / São Paulo: Itatiaia / Editora da Universidade de São Paulo, 1980).

${ }^{4}$ [...] A Anvers, Chez les heritiers de Maurice de la Porte..., 1557. Avec privilege du Roy. Alguns exemplares trazem a data de 1558. Uma segunda edição foi publicada em Paris, por Christophe Plantin, em 1558.

${ }^{5}$ Cf. Claude d'Abbeville. Histoire de la Mission... Paris: François Huby, 1614, p.12vo. A tradução brasileira citada neste artigo é a de Sérgio Milliet (História da Missão dos Padres Capuchinhos na Ilha do Maranhão e Terras Circunvizinhas. Belo Horizonte/São Paulo: Itatiaia/Editora da Universidade de São Paulo, 1975. Citação, p. 22).

${ }^{6}$ [...] A Paris, De l'Imprimerie de François Huby, M.DC.XIV. Avec Privilege du Roy.

7 [...] Second Traité. A Paris, De l'imprimerie de François Huby, ruë sainct Iacques à la Bible d'Or... M.DC.XV. Avec Privilege du Roy. A tradução dos trechos desta obra citados neste artigo é nossa.

${ }^{8}$ [...] Marpurg, bei Andress Kolben, M. D. LVII. [Verdadeira história e descrição de um país habitado por homens selvagens, nus, ferozes e antropófagos...]

9 “[...] sabendo que havia franceses na região e que era comum a chegada de naus daquela nação, insisti em continuar dizendo ser amigo deles, e roguei-lhes que me poupassem até que aqueles chegassem e me reconhecessem. Mantiveram-me cautelosamente prisioneiro 
até a chegada de alguns franceses que as naus haviam deixado com esses selvagens para que fossem em busca de pimenta”. Traduzido de Hans Staden. Op. cit., p. 83.

${ }^{10} \mathrm{O}$ termo "selvagem" é usado ao longo deste texto por razões de coerência com o vocabulário empregado pelos cronistas franceses para referirem-se ao índio americano. Lembremos, ainda, que a representação do tupinambá foi generalizada, na França, recobrindo todos os selvagens americanos, desde o século XVI, como demonstra Sturtevant, William. La tupinambisation des Indiens d'Amérique du nord. G. Therrien (Org.). Les figures de l'Indien. Montréal: Université du Québec à Montréal, 1988, pp. 293-303.

${ }^{11}$ Os colonizadores portugueses chegaram a servir-se pontualmente desses especialistas da língua, costumes e geografia de certas regiōes da costa. São múltiplos os exemplos: na transcrição do relatório manuscrito que Diogo de Campos Moreno fez da primeira expedição encarregada de expulsar os franceses, consta que os portugueses fizeram-se guiar numa expedição de reconhecimento por um "grande piloto da costa francês", chamado pelo nome indígena de Otuimiri, sem o qual jamais teriam conseguido penetrar nas terras do Maranhão em 1614. Cf. Jornada do Maranhão por Ordem de sua Magestade feita o anno de 1614. Colleção de notícias... Lisboa: Typographia da [...] Academia [Real de Sciencias], 1812, p. 2.

${ }^{12} \mathrm{O}$ termo "endotismo", que designa, no contexto em questão, o fenômeno de penetração dos franceses no tecido social indígena, é empregado por Frank Lestringant (p. 232) em excelente artigo intitulado Les débuts de la poésie latine au Brésil: le "De Rebus Gestis Mendi de Saa” (1563). De Virgile à Jacob Balde. Hommage à Mme Andrée Thill. Etudes recueillies par Gérard Freyburger. Publication du Centre de Recherches et d'Etudes Rhénanes, Université de Haute-Alsace (diffusion: Les Belles Lettres), 1987, pp. 231-245.

${ }^{13}$ Vide F. Lestringant, art. cit., p. 232.

${ }^{14}$ José de Anchieta, Cartas, informaçôes, fragmentos históricos e sermões... 1554-1594. Rio de Janeiro: Civilização Brasileira, 1993, p. 209.

${ }^{15}$ Trata-se do título do primeiro capítulo do "Relato da Missão da Serra do Ibiapaba”, do Padre Antonio Vieira. Obras Escolhidas. Lisboa: Livraria Sá da Costa Editora, 1951, vol. V, pp. 72 a 76.

${ }^{16}$ Idem, p. 74.

${ }^{17}$ Vicente do Salvador. História do Brasil (1500-1627). Belo Horizonte: Itatiaia, 1982, p. 337.

${ }^{18}$ A esse argumento poder-se-ia acrescentar outro, de ordem político-militar, pois os colonizadores portugueses temiam, antes de mais nada, os progressos técnicos e militares dos indígenas, conseqüência quase inevitável dos contatos com seus aliados franceses. Ademais, isso representava, para os missionários jesuítas, entraves significativos à catequese dos infiéis que adquiririam costumes heréticos, por assim dizer, como deixam perceber inúmeros testemunhos. Vide Ch.-A. Julien. Voyages de découverte et les premiers établissements... Paris: PUF, 1948, p. 203.

${ }^{19}$ Jean de Léry, Histoire d'un voyage, p. 223-224: “[...] quelques Truchements de Normandie, Qui aoyent demeuré huict ou neuf ans en ce pays-la, pour s'acommoder à eux, menans une vie 
d'Atheistes, ne se polluoyent pas seulement en toute sortes de paillardises \& vilenies parmi les femmes \& les filles, [...] mais aussi surpassans les sauvages en inhumanité, i'en ay ouy q se vantoyent d'avoir tué ơmangé des prisonniers". Tradução, p. 201.

${ }^{20}$ Idem, p. 71: “[... certains Normands] estoyent demeurés parmi les Sauvages, où vivans sans crainte de Dieu, ils paillardoyent avec les femmes \& filles (comme j'en ay vu qui en avoyent des enfans ja aagez de quatre à cinq ans) tant dis-je pour reprimer cela, que pour obvier que nul de ceux qui faisoyent leur residence en nostre isle \& en nostre fort n'en abusast de cette façon: Villegaignon, par l'advis du Conseil fist deffense à peine de la vie, que nul ayant titre de Chrestien n'hasbitast avec les femmes des Sauvages [...]." Tradução, p. 96.

${ }^{21}$ Idem, p. 84: “[... nous] frequentions, mangions \& beuvions parmi les Sauvages, lesquels sans comparaison nous furent plus humains que celuy [Villegaignon] lequel sans luy avoir meffait ne nous peut souffrir avec luy." Tradução, p. 102: "amiúde visitávamos os selvagens pelos quais éramos tratados com mais humanidade do que pelo patrício que gratuitamente não podia nos suportar, e comíamos e bebíamos entre eles."

${ }^{22}$ Cf. Archivum Romanum Societatis Jesu, Bras. 8 I, f. 152. Quanto ao termo "geração" — assim como "nação" ou "linhagem" — , foi utilizado pelos portugueses, ao longo de todo o século XVI, para designar as diferentes "etnias" no âmbito da grande família tupi do Brasil. No contexto da passagem citada, o emprego da palavra "geração" parece igualmente remeter ao seu sinônimo "progenitura".

${ }^{23}$ Idem.

${ }^{24}$ É precisamente em termos da união de duas naçôes, a francesa e a tupinambá, que Claude d'Abbeville se expressa ao longo do seu relato, particularmente no prefácio.

${ }^{25}$ Yves d'Evreux. Voyage dans le Nord du Brésil fait en 1613 et 1614. Leipzig \& Paris: Librairie A. Franck, 1864, p. 39: "Les Indiens avaient coutume de donner leurs filles à leurs compères, celles-ci prennent dès lors le prénom de Marie et le nom du Français, pour désigner l'alliance avec tel Français, de sorte que dire 'Marie une telle', c'était autant dire la concubine d'un tel [...] Cette coutume de prendre les filles des Sauvages a été défendue aux Français et cela ne se fait plus, si ce n'est occultement."

${ }^{26}$ Claude d'Abbeville. Op. cit., p. 165 a 170 (tradução, pp. 126 a 129).

${ }^{27}$ Idem, p. 169: “[...] ORDONNONS de ne commettre aucun adultère qu'il soit par amour ou par force avec les femmes des Indiens sur peine de la vie [...] \& deffendons aussi la force envers les filles sur la mesme peine de la vie. ORDONNONS \& deffendons à toutes personnes de quelque qualité quils soient, de ne commettre aucune paillardise en quelque sorte avec les filles desdits Indiens [...].” Tradução, p. 128. Mais genérica e impessoal, a última dessas três "ordenaçōes" interdita a qualquer pessoa "quaisquer roubos contra os índios, seja de suas roças, seja de outras cousas que lhes pertençam, sob as penas supra mencionadas”.

${ }^{28} \mathrm{O}$ estabelecimento das leis no interior da colônia francesa do Maranhão se justifica, nos próprios termos de Claude d'Abbeville, por uma "estreita ligação entre a religião e a lei [...] em se mudando a religião e o ofício sacerdotal, mister se faz mudar-se a lei”. Claude d'Abbeville. Op. cit., p. 165 (tradução, p. 126). 
${ }^{29}$ Idem, p. 104 (tradução, p. 84). Não restam dúvidas, todavia, que alguns desses truchements gozaram de um prestígio perfeitamente legítimo junto à companhia francesa, como é o caso de Migan, um normando de Dieppe que coabitava há anos com os tupinambás e era grande conhecedor das tribos locais. Migan possuía um status sem dúvida significativo na França Equinocial, pois o vemos, por exemplo, assinar, junto dos lugartenentes-gerais, como testemunha da carta na qual La Ravardière expõe suas razões para retornar à França antes do término da expedição (Claude d'Abbeville. Op. cit., p. 332; tradução, pp. 257-258).

${ }^{30}$ Claude d'Abbeville. Op. cit., p. 74: “Mais je m'estonne comme il se peut faire que vous autres Pay ne vouliez pas de fermmes. Estes vous descendus du Ciel? Estes vous nays de Pere et Mere? Quoy donc! N'estes vous pas mortels comme nous? D'où vient que non seulement vous ne prenez pas de fermmes ainsi que les autres François qui ont trafiqué avec nous depuis quelques quarente \& tant d'annees. Mais encore que vous les empschez maintenant de se servir de nos filles: ce que nous estimions à grand honneur \& un grand heur, pouvans en avoir des enfants?" Tradução, p. 63.

${ }^{31}$ A importância da noção de "singularidade" é confirmada por uma série de títulos de obras francesas, como as de Claude d'Abbeville ou a de André Thevet, assim como por toda uma tradição cultural renascentista que atinge o seu ponto culminante com a obra deste último, guardião do "Cabinet des Singularitez du Roi aux Tuileries". Vide Frank Lestringant. Fortunes de la singularité à la Renaissance: le genre de l'Isolario. Studi francesi, no 84, anno XXVIII, fasc. III, set.-dez., 1984, pp. 415-436.

32 Título do capítulo XLVIII de Yves d'Evreux. Voyage dans le Nord du Brésil, pp. 188-193.

${ }^{33}$ Idem: "l'infinité de jeunes gentilshommes qui nont rien que l'épée et le poignard pour fortune."

${ }^{34}$ Idem: "Vous passeriez le temps tandis que votre coeur s'apaiserait et que votre jugement s'affermiarit, vous feriez service à Dieu et à votre roi en visitant cette Nouvelle France."

${ }^{35}$ Idem, p. 192.

${ }^{36}$ Idem: “... telles cotons, literies, les casses, les bois de diverses couleurs, la pite, les teintures de roucou, de cramoisi, les poivres longs, le lapis-lazuli, le cuivre, l'argent, l'or, les pierres précieuses, les plumasseries, les oiseaux de diverses couleurs, les singes et sapajous, et sourtout les sucres quand on aura dressé des moulins et planté des cannes." [“... tais como os algodões, camas de tecido, as madeiras de diversas cores, a pita, as tinturas de roucou, púrpura, as pimentas longas, o lápis lazúli, o cobre, a prata, o outro, as pedras preciosas, as plumas, os pássaros de diversas cores, os macacos sagüis e, sobretudo, os açúcares, quando se tiverem erguido moinhos e plantado canas."]

${ }^{37}$ É muito provável que Yves d'Evreux estivesse se referindo, na passagem acima, à primeira expedição de 1612, ainda que ele não forneça qualquer precisão cronológica ou contextual. Esse tipo de observação se insere perfeitamente no âmbito "programático" de sua narrativa, que visa persuadir não somente o rei de França e "o leitor francês", aos quais se dirige, mas também qualquer comanditário ou colono da pertinência do sistema de escambo brasileiro. Quanto às mercadorias que foram objeto de troca quando dos primeiros contatos entre tupinambás e franceses em 1612, apontamos a passagem da carta de Pezieu "aos senhores seus parentes e amigos de França” (Brief Recueil, p. 8): “... nous 
croyons d'avoir tant de marchandises que nous avons apporté, que de celles dont $M$. du Manoir nous a accomodé suffisament, pour traiter \& entretenir ce peuple, jusques au retour dudit sieur de Razilly. J'ay desja fait amitié avec les principaux d'entre-eux: mais li m'en coustrea des casaques, commençans desja à prendre goust à se vestir." [“...cremos possuir tanto as mercadorias que trouxemos, quanto aquelas de que o sr. du Manoir nos aprovisionou suficientemente, para tratar e entreter esse povo, até o retorno do referido senhor de Razilly. Ja fiz amizade com os principais dentre eles: mas isso me custará casacos, pois já começaram a tomar gosto de vestir-se."] Ele acrescenta (p. 9) que a necessidade "de mercadorias para ampliarem-se as relaçôes e traficar com eles [índios], apressou o retorno de Razilly [à França]." ["(La nécessité) de marchandises pour se dilater \& trafficquer avec eux, a faict haster le retour de Razilly”.]

${ }^{38}$ Yves d'Evreux, Idem: “Ils n'ont rien voulu faire et ne feront rien tant que les Français n'auront rien à leur donner en récompense, car tel est leur naturel... Ils ne sont pas blâmables en cela, puisqu'en toute la chrétienté vous ne trouverez pas un seul homme qui veuille travailler pour rien."

${ }^{39} \mathrm{O}$ capítulo intitula-se "Instruções para aqueles que vão recentemente às Índias". Yves d'Evreux. Op. cit., p. 195: “... ayez force couteaux à manche de bois dont usent les bouchers [...], des ciseaux de malle en quantité, force peignes, miroirs, grains de verre de couleur pers qu'ils appellent rassade, serpes, haches, couperets, des chapeaux de petit prix, des manteaux, chemises, haut-de-chausses de friperie, de vieilles épées et qrquebuses de peu de coût. Ils font grand cas de tout ceci, et vous aurez le moyen d'avoir d'eux des esclaves et de bonnes marchandises." [“... tende muitas facas com cabo de madeira, daquelas de que se servem os açougueiros [...], tesouras em quantidade, muitos pentes, espelhos, contas de vidro colorido que eles chamam rassade, foices, machados, cutelos, chapéus baratos, casacos, camisas, calções de loja de segunda mão, espadas e arcabuzes velhos de baixo custo. Eles [os selvagens] dão muito valor a tudo isso, e tereis os meios de obter deles escravos e boas mercadorias."]

${ }^{40}$ Idem, p. 196.

${ }^{41}$ Idem: "S'il y a nation au monde portée à faire bon accueil à ses amis nouvellement arrivés, à les recevoir dans les maisons pour les traiter aussi bien que possible, les Tapinambos envers les Français doivent tenir le premier rang [...]".

${ }^{42}$ Idem, p. 197: "Voilà les navires de France qui viennent, se dit le sauvage, je ferai un bon compère: il me donnera des haches, des serpes, des couteaux, des épées et des vêtements; je lui donnerai ma fille, jïrai à la chasse et á la pêche pour lui, je ferai force cotons, je chercherai des aigrettes et de l'ambre pour lui donner [...]".

${ }^{43}$ Essas páginas constituem, na verdade, o segundo ato de um diálogo franco-tupi, reproduzido anteriormente por Jean de Léry em sua Histoire d'un voyage. O tema do escambo foi assim abordado por duas vezes nos relatos franceses sobre o Brasil, sob a forma de diálogo exemplar bilíngüe. Em Léry, ele aparece como uma suposta reprodução de uma prática freqüentemente repetida (os gestos do escambo estando estreitamente vinculados ao desenrolar desses diálogos). Em contrapartida, para Yves d'Evreux, a transcrição é menos 
o resultado de uma observação do que a divulgação de um "programa” a ser seguido. Vide também Jean de Léry. Histoire d'un Voyage, pp. 307 a 327.

${ }^{44}$ Cf. André Thevet. Cosmographie Universelle. Paris: Guillaume Chaudière, 1715, p. 95 : "Les navires seront quelquefois loing du lieu ou se fait la couppe, quatre ou cinq lieues, \& tout proffit que ces pauvres gens ont de tant de peine, ce sera quelque meschant chemise, ou de la doublure de quelque accoustrement de peu de valeur." ["Os navios estarão por vezes distantes do local onde se faz o corte, a quatro ou cinco léguas, e tudo que essa pobre gente conseguirá em troca de tanto sacrifício, será uma camisa mal feita, ou o forro de alguma vestimenta de pouco valor."]

${ }^{45}$ Cf. Patricia Olive Dickason. The Brazilian Connection: a Look at the Origin of French Techniques for Trading with Amerindians. Revue Française d'Histoire d'Outre-Mer, t. LXXI (1984), no 264-265, p. 129: "While concomitant for part of the sixteenth century with the fur trade of the north, this Franco-Brazilian trade had started earlier and peaked much sooner". ${ }^{46}$ É a tese proposta por Patricia Olive Dickason, art. cit., p. 129 a 146.

${ }^{47}$ Vide Ferdiand Denis. Une fête brésilienne. Bulletin du Bibliophile. Paris: Teuchner, 1849 e Afonso Arinos de Melo Franco. O Indio Brasileiro e a Revolução Francesa. As Origens Brasileiras da Bondade Natural. Rio de Janeiro: José Olympio, 1976, 2ª edição, pp. 46 a 53. ${ }^{48}$ C'est la deduction du sumptueux ordre... A Rouen, Chez Robert le Hoy et Jehan dictz du Gord, [1551]. Eis a passagem citada, em sua integralidade: “... que les mariniers de ce pays ont accoustumé faire quand ils traictent avec les Brisiliens [...] lequel bois iceulx sauvages troquoient et permutoient aux mariniers dessusditz, en haches serpes et coings de fer, selon leur usage et leur maniere de faire. La troque et commerce ainsi faite, le boys etoit batellé par gondolles et esquiffes, en un grand navire à deux Hunes ou gabyes radiant sur ses ancres [...]: l'artillerie rangée par les lumières et sabortz en proue qu'en poupe et le long des escorttartz." [“...madeira essa que os selvagens trocavam e permutavam com os supracitados marinheiros, por machadinhas, foices e cunhas de ferro, segundo seu uso e sua maneira de fazer. Uma vez terminado o escambo e o comércio, a madeira era transportada por gôndolas e esquifes, até um grande navio de duas gáveas a cintilar seguro às âncoras [...]: nos navios de escolta, a artilharia alinhada pelas almas e portinholas, tanto na proa quanto na popa e ao longo de todo o comprimento."]

${ }^{49} \mathrm{Na}$ ordem do cortejo, uma batalha naval é simulada em seqüência à "cena dos brasileiros": uma nau é destroçada, conquistada e por fim abandonada às chamas. A hipótese de J.-M. Massa é a de que se trata de um combate franco-lusitano. Ele sugere que, aos olhos do embaixador de Portugal, convidado à festa real, a imagem dessa naumaquia (simulação de uma batalha naval) teria uma relação intrínseca com a "cena" brasileira que a precede. Cf. J.-M. Massa. Le monde lusobrésilien dans la Joyeuse Entrée de Rouen. Les Fêtes de la Renaissance. Paris: Editions du CNRS, 1975, tomo III, pp. 105 a 116.

${ }^{50}$ Sobre o pergaminho encontra-se a inscrição "Esta carta foi realizada no Havre da Graça por Pierre Devaulx, Piloto Geógrafo do Rei. Ano de 1613”.

${ }^{51}$ Pezieux, em seu BriefRecueil (op. cit., p. 21), fala explicitamente de alcançar o Peru pelos rios que atravessam a região das Amazonas. 
52 Para mais detalhes, vide F. Lestringant. La littérature géographique du temps de Henri IV. Les lettres au temps de Henri IV. Colloque d'Agen-Nérac 1990. Pau: J. \& D. Editions, 1991, p. 299.

${ }^{53}$ A economia do escambo havia dado provas suficientes de prosperidade, pelo menos até o início do século XVII, com o projeto colonial do Maranhão. Os termos do autor de um manuscrito anônimo conservado em Turim, que revela em detalhes os preparativos da expedição e seu contexto político-financeiro, exprimem uma certa preeminência do tráfico brasileiro sobre o canadense em 1612 e, de certo modo, sua maior "fiabilidade": "Plusieurs qui auoient suivi Poutrincourt au Canada ou ils n'auroient rien d'autre de quoi trafiquer que des castors et des fourrures, prirent ce parti comme plus apparent." ["Vários daqueles que teriam seguido Poutrincourt ao Canadá, onde nada mais teriam para traficar do que castores e peles, consideraram essa opção (a expedição do Maranhão) como mais atraente."]

${ }^{54}$ Sobre o posicionamento pré-etnográfico de Jean de Léry, anterior à disciplina Etnografia, que data do século XIX, vide Michel de Certeau. Ethno-graphie. L'oralité ou l'espace de l'autre: Léry. L'Ecriture de l'Histoire. Paris: Gallimard, 1975, pp. 215-248. É possível também que essa postura pré-etnográfica se deva, em grande parte, a uma idealização do selvagem brasileiro, produto ulterior das tentativas abortadas de estabelecimento colonial. É a hipótese de grande pertinência proposta por Frank Lestringant em Le Huguenot et le Sauvage, p. 272.

55 Guy Martinière, em um artigo intitulado Henri IV e a França Equinocial. Actes $d u$ Colloque sur le 4e centenaire de l'avènement d'Henri $I V$, p. 439, discute, do ponto de vista político-econômico, os métodos de colonização frente aos tipos de relações humanas estabelecidas entre europeus e os índios do Brasil, e conclui: "A sorte desse humanismo francês frente aos índios se deve, portanto, a um duplo atraso da colonização francesa: um primeiro atraso que obriga a seduzir populaçôes cujo território é considerado como conquistado pelo portugueses; um segundo atraso que se deve à continuidade de uma prática de troca baseada no escambo durante quase um século, enquanto os portugueses já carecem de uma mão de obra local disponível e numerosa para assegurar a produção de um novo ciclo exportador do Brasil, o açúcar, que sucede ao ciclo do pau-brasil."

${ }^{56}$ Yves d'Evreux. Op. cit., p. 81. Ademais, como nos relatos de Léry ou de Claude, a argumentação de Yves d'Evreux sobre o "natural indígena" é acompanhada da crítica à sociedade ocidental. Assim, o extraordinário potencial de civilização dos tupinambás contrasta, sem dúvida, com o canibalismo, que o Padre Yves compara ao "erro de nossos franceses de se cortarem a garganta em duelo" ["l'erreur de nos Français de se couper la gorge en duel']. ${ }^{57}$ No próprio âmbito do catolicismo missonário, somos levados, ainda, a pensar o que a diferencia do posicionamento dos jesuítas portugueses.

${ }^{58}$ Vide, neste caso, Manuela Carneiro da Cunha. Imagens de Indios do Brasil: o Século XVI. Estudos Avançados. São Paulo: Instituto de Estudos Avançados, vol. 4, n. 10, set./ dez. 1990, pp. 91-110, que lança a seguinte conclusão: "Pelo fim do século [XVI], estão consolidadas, na realidade, duas imagens de índios que só muito tenuamente se recobrem: a francesa, que o exalta, e a ibérica, que o deprecia. Uma imagem de viajante, outra de colono." 
59 Pode-se citar, em oposição à tese da visão depreciadora do colonizador versus a visão tolerante do "estrangeiro" em relação ao índio, a reflexão mais pertinente e cuidadosa de Hélènes Clastres, no que diz respeito aos Capuchinhos franceses: "En Maranhão, là où ils venaient eux aussi en colonisateurs [sic], les Français surent apparemment se montrer plus tolérants que les Portugais." Prefácio a Yves d'Evreux. Voyage dans le nord du Brésil. Paris: Payot, 1985, p. 14.

${ }^{60}$ Manuel da Nóbrega. Diálogo sobre a conversão do gentio... Serafim Leite. Cartas dos primeiros Jesuitas do Brasil. São Paulo: Comissão do IV Centenário da cidade de São Paulo, 1954, vol. II. No Diálogo de Nóbrega, os índios, embora descendentes legítimos de Cam e portadores de sua maldição, são convertíveis, quando superadas algumas das dificuldades que se impõem ao missionário. Estas dificuldades são oriundas, sobretudo, de seus costumes bárbaros e contra-natureza, sinais possíveis de fraqueza da memória e da vontade, mas não de falta de entendimento, segundo o Jesuíta. Apesar da aparência equívoca, resultante da dessemelhança de polícia de todos os gentios, pagãos e idólatras fruto tão simplesmente de criação diversa, para Nóbrega —, o entendimento natural é extensivo a toda a humanidade, o que, segundo o Diálogo, torna accessível a graça aos tupinambás.

${ }^{61}$ Jean de Léry. Op. cit. pp. 230-261: “Ce qu'on peut appeler religion entre les Sauuages Ameriquains: des erreurs, ou certains abuseurs qu'ils ont entr'eux nommez Caraibes les detiennent: \& de la grande ignorance de Dieu où ils sont plongez". Tradução, p. 205: "Religião dos Selvagens da América ; Erros em que são mantidos por certos trapaceiros chamados Caraíbas; ignorância de Deus."

${ }^{62}$ Idem, pp. 260-261: "Dautant doncques quant à ce qui concerne la beatitude \& felicité eternelle [...] nonbstant les sentiments que i'ay dit, qu'ils [les Tupinamba] en ont: c'est vn peuple maudit \& delaissé de Dieu, silly en a un autre sous le ciel [...], il semble qu'ily a plus d'apparence de conclure qu'ils soyent descendus de Cham [...]: il pourrait être aduenu (ce que ie di sous correction) que les Maieurs \& ancestres de nos Ameriquains, ayans esté chassez par les enfans d'Israel de quelques contrees de ce pays de Chanaan, s'estan mis dans des vaisseaux à la merci de la mer, auroyent esté iettez \& seroient abordez en ceste terre d'Amerique." Tradução, p. 221.

${ }^{63}$ Idem, p. 120: "l'objet d'une malédiction particulière qui se surajoute à celle du péché originel commune à tous les hommes."

${ }^{64}$ Cf. Claude d'Abbeville, Histoire de la Mission, p. 7.

${ }^{65}$ Este argumento aparece muito explicitamente no Prefácio da Histoire de la Mission, p. 5v: "[Les Tupinamba] voulans fuir la cruauté \& tyrannie de leurs ennemis ont esté contraincts de quitter leur patrie, \& lieux de leur natiuité pour se refugier en ces isles maritimes, \& lieux voisins de la mer où ils sont maintenant" Tradução, p. 16: "Os tupinambá, querendo fugir à crueldade $\&$ tirania de seus inimigos se viram forçados a deixar sua pátria, \& as regiões em que nasceram para refugiarem-se nessas ilhas marítimas, \& lugares vizinhos do mar onde estão agora..."

${ }^{66}$ Idem, p. 94.

${ }^{67}$ De fato, a condenação do selvagem brasileiro é parte integrante do conteúdo teológico deste mesmo capítulo XVI. Léry teria adquirido esta cultura teológica com uma tintura 
de purismo, depois de seu retorno de Genebra, como afirma Frank Lestringant, Le Huguenot et le Sauvage. Paris: Aux Amateurs de Livres, 1990, p. 50. Vide também, do mesmo autor, Les Indiens antérieurs (1575-1615): Du Plessis-Mornay, Lescarbot, De Laet, Claude d'Abbeville . G. Therien (Org.). Les figures de l'Indien, Montréal: Université du Québec à Montréal, 1988, pp. 51-75.

${ }^{68}$ Claude d'Abbeville. Op. cit., p. 70: “.. privée non seulement de la belle lumière \& de la connoissance de ce grand Toupan, mais aussi de la conversation des François."

${ }^{69}$ Claude d'Abbeville. Op. cit. p. 70-70v: “[... ] i'ay grande esperance en ta bonté, \& douceur: car tu me sembles avoir parmy ta façon guerriere, une façon douce, \& d'un personnage qui nous gouvernera fort sagement; \& te diray là dessus, que tant plus un homme est nay grand \& avec de l'authorité sur les autres, d'autant doit il estre doux, gracieux \& clement. Car les hommes, \& principalement ceux de cette nation, se rangent plus facilement par la douceur, que par la violence." Tradução, p. 61.

${ }^{70}$ Claude d'Abbeville. Op. cit.., p. 71v: "Ce n'est ny la beauté, ny les richesses de ton pays qui mont aménés icy [...] Mais seulement le désir que i'ay qu'apres vostre vie vos ames soient reservées de la damnation éternelle, \& des tourmens de Ieropary comme aussi pour mettre vos corps, vos biens \& vos familles hors d'aprehension de l'invasion de vos ennemis: voila les deux raisons qui mont induit à vous venir trouver." Tradução, p. 62.

${ }^{71}$ Idem, pp. 68-69: "Ie suys tres ayse, vaillant guerrier de ce que tu es venu dans cette terre pour nous rendre heureux, \& nous defendre de nos ennemis. Nous commencions desia à nous ennuyer tous [...] \& ja nous nous deliberions de quitter cette coste, \& abandonner ce pays pour la crainte que nous avions des Pero (c'est à dire Portugais) nos mortels ennemis...". Tradução, p. 59.

${ }^{72}$ Claude d'Abbeville. Op. cit.., p. 70-70v: "Pour mon regard i'ay touiours pratiqué cette maxime avec ceux sur lesquels i'ay eu commandement, \& m’en suis bien trouvé. I'ay touiours aussi remarqué cette douceur parmy les François: que si nous eussions trouvé autres que bons, nous nous en fussions tous allés à travers les bois, où l'on eut sçeu nous suivre..." Tradução, p. 61.

${ }^{73}$ Segundo F. Lestringant (Le Huguenot et le Sauvage), haveria um fantasma de identificação entre o huguenote e o selvagem, como bem sugere o título de seu livro.

${ }^{74}$ Não é negligenciável o fato de que a Histoire d'un voyage tenha tido uma recepção notável, mesmo fora dos limites do partido huguenote. Frank Lestringant afirma, a partir do estudo do P. Dainville, que "la vogue de Léry contamine l'enseignement des Jésuites [...] lesquels quand il s'agit de faire cours sur les contrées lointaines des Cannibales, se réfêrent à l'hérétique auteur de l'Histoire de 1578 aussi bien qu'à son rival catholique [André Thevet]." Cf. F. Lestringant. Op. cit. p. 130. Visivelmente, o pessimismo de Léry quanto à conversibilidade dos selvagens e seu posicionamento anticolonial, expresso na virulência de seu ataque a Villegaignon, não bastaram para abalar as esperanças dos leitores mais fiéis de seu relato quanto a um futuro colonial francês na América.

${ }^{75} \mathrm{~A}$ última edição da Histoire d'un voyage saiu 4 anos antes da publicação da Histoire de la Mission. Jean de Léry foi amplamente compilado por seus contemporâneos, protestantes e católicos, tais como Jacques-Auguste de Thou, La Popelinière, Marc Lescarbot e Gilbert Génébrard. Cf. F. Lestringant. Op. cit. p. 129. Quanto à recepção de Jean de Léry no pe- 
ríodo clássico, ver o Epílogo de F. Lestringant à edição do livro de Léry, Histoire d'un voyage fait en la terre du Brésil, Aubenas d'Ardèche, Presses du Languedoc/Max Chaleil Editeur, 1992, p. 231. Sobre o parentesco entre as obras de Jean de Léry e de Claude d'Abbeville, vide o artigo de Elena Semeria, Jean de Léry e Claude d'Abbeville: parentele e dipendenze. Studi Francesi. Anno XXX, fascicolo I. Torino: Rosenberg \& Sellier Editori, gennaio-aprile 1986, pp. 65-71. Por vezes, as traduções dos trechos parafraseados, citados acima, são menos semelhantes em português, pelo caráter mutilador das traduções disponíveis que optamos por citar.

${ }^{76}$ Jean de Léry. Op. cit.., p. 231: “Combien que cette sentence de Ciceron, assauoir qu'il n'y a peuple si brutal, ny nation si barbare et sauvage qui n'ait sentiment qu'ily a quelque Diuinité soit reçue et tenue [...] pour une maxime indubitable: tant y a neantmoins que quand ie considere [...] nos Tououpinambaoults de l'Amerique, ie me trouve aucunement empesché touchant l'application d'icelle en leur endroit. Car ils ne confessent ny adorent aucuns dieux celestes ny terrestres [...] ils ne prient par forme de religion ny en publique ny en particulier. [...] Ils ne distinguent point les iours par noms, ny n'ont acceptation de l'un plus que de l'autre: comme aussi ils ne content sepmaines, mois ny annees, ains seulement nombrent et retiennent le temps par lunes..." Tradução, p. 205.

${ }_{77}$ Claude d'Abbeville. Op. cit.., p. 322: “Ie n'estime pas qu'ily ait aucune nation au monde laquelle ait esté sans aucune espece de religion sinon les Indiens Tupinamba, lesquels n'ont cy deuant adoré aucun Dieu, ny Coeleste ny terrestre [...] Ils n'ont iamais sceu que c'est ny de voeux, ny de prieres, ny d'oraison soit publique ou particulière. Ils content bien les lunes, mais n'en font distinction ny des sepmaines, ny des festes ou Dimanches." Tradução, p. 250.

${ }^{78}$ Claude d'Abbeville utiliza, por vezes, as mesmas expressões que Jean de Léry para definir alguns aspectos morais dos tupinambás. É o caso do exemplo da passagem dedicada às virtudes heróicas que fazem dos grandes guerreiros homens felizes, e dos "effeminez ou covards" homens entregues ao tormento do Diabo, Ieropary. Léry os havia definido, anteriormente, como "effeminez et geans de neant" e "effeminez et lasches de coeur". Claude d'Abbeville. Op. cit., p. 323 e Jean de Léry. Op. cit., p. 234 et 197. Cf. Elena Semeria, art. cit., p. 67.

${ }^{79}$ Claude d'Abbeville. Op. cit.., p. 280: "Pour le regard des enfants des Indiens bien tost apres qu'ils sont naiz les peres les frottent de ces huiles et peintures, ainsi que nous avons dict cy deuant et puis ils les couchent dans des petits lits de cotton suspendus en l'air, sans iamais les emmailloter ny couurir aucunement. I'estime que c'est en partie pour cela qu'ils ne sont pas si suiects à estre courbez et contrefaicts ainsi que plusieurs de pardeçà qui sont des leurs naissances enserrez dedans leurs berceaux et toutes leurs vies dans des accoutrements si estroits, que la nature estant comme prisonnière et violentée, elle ne peut croistre qu'auec beaucoup de peine et de difficulté, d'où viennent tant de boiteux et bossus. Il n'en est pas ainsi des Indiens qui laissent croistre la nature auec toute liberté, aussi y a il le plaisir à voir principalement ces petits enfants." Tradução, p. 224. ${ }^{80}$ Jean de Léry. Op. cit.., p. 266: “Comme aussi incontinent que le petit enfant est sorti du ventre de la mère, estant laué bien net, il est tout aussi peinturé de couleurs rouges et noires, par le père; lequel, au surplus, sans l'emmailloter, le couchant sur un lict de cotton pendu en l'air [...] Or, retournant à mon propos, quoy qu'on estime communnément par-deçà, que si les enfants, 
en leurs tendres et premieres ieunesse n'etoyent bien serrez et emmaillotez, ils seroyent contrefaits, et auroyent les iambes courbées: ie dis qu'encore que cela ne soit nullement obserué à l'endroit de ceux des Ameriquains [...] Il me semble, qu'il vaudroit mieux laisser au large les petits enfans gambader tout à leur aise parmi quelque façon de licts qu'on pourroit faire, dont ils ne sauroyent tomber, que de les tenir tant de cour. Et de fait, i'ay opinion que cela nuit beaucoup à ces pauures petites et tendres creatures d'estre ainsi, durant les grands chaleurs eschauffees, et comme à demi cuites, dans ces maillots où on les tiens comme en la gehenne." Tradução, p. 225-226.

${ }^{81}$ Cf. F. Lestringant, Le Huguenot et le Sauvage, p. 130.

${ }^{82}$ Claude d'Abbeville. Op. cit.., p. 270v'-271: "Plusieurs croyent que c'est une chose bien monstrueuse de voir ce peuple tout nud \& qu'ily a bien de danger de frequenter parmy les filles et les femmes indiennes estans nues comme elles sont [...] mais en effect ie puis dire qu'ily a sans comparaison beaucoup moins de danger à voir la nudité des Indiennes que la curiosité des attraicts lubriques des Dames mondaines de la France... la nudité de soi n'estant peut estre si dangereuse ny si attrayante que sont les attisets lubriques auec les effrenés mignardises \& nouuelles inuentions des Dames de par-deçà...” Tradução, pp. 216-217.

${ }^{83}$ Jean de Léry. Op. cit.., p. 114: "Toutesfois [...] ce lieu-ci requiert que ie responde, tant à ceux qui ont escrit, qu’à ceux qui pensent que la frequentation entre ces saunages tous nuds, et principalement parmi les femmes, incite à la lubricité et à la paillardise [...]. Cette nudité ainsi grossière en telles femmes est beaucoup moins attrayante qu'on ne cuideroit. Et partant, ie maintien que les attisets, fards, fausses perruques, cheueux tortillez grands collets fraisez, vertugales et autres infinies bagatelles dont les filles et femmes de pardeçà se contrefont [...] sont sans comparaison cause de plus de maux que n'est la nudité ordinaire des femmes sauvages." Tradução, p. 121. Sobre a questão do aleitamento materno, na perspectiva da crítica às sociedades ocidentais, a paráfrase também é verificada (Histoire d'un voyage, p. 267. Histoire de la mission, p. 281). Cf. E. Semeria. Op. cit., p. 69.

${ }^{84}$ Vide o Prefácio de J. Lafaye à edição fac-similar da Histoire de la Mission, p. XXIII.

${ }^{85}$ Vide o Epílogo de F. Lestringant. Op. cit., pp. 263 à 273, considerando-se o anacronismo da noção de "literatura" para o século XVI.

${ }^{86}$ As expressões par-delà e par-deçà, dentro da lógica de composição circular dos relatos de viagem de língua francesa - particularmente os de Jean de Léry e de Claude d'Abbeville - correspondem respectivamente ao espaço americano e ao europeu. Note-se que os termos opostos par-deçà e par-delà, significando respectivamente França e Brasil, expressam toda a polaridade contida na análise da sociedade indígena e na crítica à sociedade ocidental européia, em Jean de Léry (e, na sua herança, em Claude d'Abbeville). Vide, sobre Léry, Michel de Certeau. Ethno-graphie. L'oralité ou l'espace de l'autre: Léry. L'Ecriture de l'Histoire. Paris: Gallimard, 1975, pp. 215-248.

${ }^{87}$ Jean de Léry. Op. cit.., p. 94-95: “... les sauvages de l'Amerique habitans en la terre $d u$ Brésil [...] n'estans point plus grands, plus gros ou plus petits de stature que nous sommes en l'Europe, n'ont le corps ny monstrueux ny prodigieux à nostre esgard: bien sont ils plus forts, plus robustes et replets, plus dispos, moins suiets à maladie: et mesme il n'y a presque point de boiteux, de borgnes, contrefaits, ny maleficiez entre eux. Dauantage, combien que plusieurs paruiennent iusques à l'aage de cent ou six vingt ans [...] peu y en a qui en leur vieillesse ayent 
les cheueux ny blancs ny gris. Choses que pour certain monstrent non seulement le bon air \& bonne température de leur pays, [...] mais aussi [...] le peu de soin et de souci quills ont des choses de ce monde. Et de fait, [...] tout ainsi quills ne puisent, en façon que ce soit, en ces sources fangeuses, ou plustost pestilentiales, dont decoulent tant de ruisseaux qui nous rongent les os, succent la moele, attenuent le corps, \& consument l'esprit: brief nous empoissont \& font mourir par-deçà, deuant nos iours: assauoir, en la desfiance, en l'auarice qui en procede, aux procez et brouilleries, en l'enui et l'ambition, aussi rien de tout cela ne les tourmente, moins les domine \& passionne". Tradução, pp. 111-112.

${ }^{88}$ Claude d'Abbeville. Op. cit..., p. 287: "[Les Indiens Toupinamba...] estan tous naturellement d'une belle taille et des mieux proportionez, partie pour la temperature du pais, partie à la raison quills ne sont forcez ny violentez ou contraincts comme les Mignons de par-deçà, par des habits qui les serrent [...] vous ny en voyez presque point de borgnes entre eux, ny d'auengles, ny de bossus, ny de boiteux ou autres contrefaits par quelque deformité [...] Ils sont merveilleusement alaigres \& dispos \& beaucoup plus forts \& robustes sans comparaison que sont les plus forts de par-deçà. Ils ne sont pas valetudunaires ny malsains [...] Ne voyons nous pas plusieurs maladies arriver à beaucoup de personnes de cholere, de tristesse de crainte \& d'autres affections dereglées? Combien y en a il qui tombent en diuerses infirmitez par l'air corrompu \& par une trop grande repletion, particulièrement par la violence de vin pris par excès \& immoderement? [...] Mais en ce pais là ils ne sont ordinairement maleficiez ou accidentez, [...] au contraire ils sont de bonne \& forte complexion... L'air y est si salubre quills ne meurent guere que de vieillesse \& par le deffaut de nature plust tost que par quelque maladie, vivans pour l'ordinaire cent, six vingt ou sept vingt ans." Tradução, p. 211.

${ }^{89} \mathrm{O}$ relato de Claude d'Abbeville foi publicado numa edição bastante luxuosa, em 1614. A proximidade das datas do Privilégio Real (24 de janeiro de 1614) e das Aprovaçóes do Padre Provincial dos Capuchinhos de Paris (17 de janeiro), do Primeiro Definidor do Convento dos Capuchinhos (23 de janeiro) e do Comissário Provincial da Missão das Índias Ocidentais ( 23 de janeiro), levam-nos a afirmar as condiçóes apressadas de publicação do livro, num contexto de "propaganda" da missão do Maranhão, em vista da obtenção do apoio necessário - financeiro, logístico e material — por parte da Coroa e dos investidores, para a saída de uma segunda expedição rumo ao Maranhão.

${ }^{90}$ Vide o Epílogo de Frank Lestringant a Histoire d'un voyage, p. 242, e do mesmo autor, Le cannibalisme des cannibales. De Montaigne à Malthus. Bulletin de la Société des Amis de Montaigne, $\mathrm{VI}^{\mathrm{e}}$ série, n. 11-12, juillet-décembre 1982, pp. 19-38.

${ }^{91}$ Segundo Lestringant, "par son portrait du Bon Sauvage Tupinamba, Léry anticipe les conquêtes politiques et morales de ses coreligionnaires, et contribue puissament à la propagande du groupe de pression huguenot dans les divers pays d'Europe du Nord' (F. Lestringant. Le Huguenot et le Sauvage, pp. 127-128). No entanto, nos anos 1580, teria havido, ainda segundo Lestringant, uma guinada em direção a uma política colonizadora protestante. Foi então que, nos meios reformados, o mito do selvagem convertível desenvolveu-se conjuntamente ao do Espanhol cruel e usurpador.

${ }^{92}$ F. Lestringant, Prefácio a Jean de Léry, Histoire d'un voyage, p. 11. O anti-colonialismo de Léry leva-o a pôr em causa o direito de ocupação e de colonização das terras america- 
nas, como afirma Lestringant: “C'est pour cette raison que Léry apparaît en définitive comme un anti-colonialiste: l'Indien étant inconvertible, ainsi que l'échec de la colonie française du Brésil l'a montré, les Espagnols et les Portugais n'ont aucun droit à occuper ses terres sous prétexte d'évangélisation. A l'instar de ses coreligionnaires, Léry adhère sans restriction à la "leyenda negra" anti-espagnole, tirée par le parti huguenot des écrits du Dominicain Bartolomé de Las Casas. Léry peut bien dénoncer les horreurs commises au nom de la croix. Dans le moment même où il est écarté du rachat, l'autre est protégé dans son intégrité physique."

${ }^{93}$ Vide Frank Lestringant, Prefácio a J. de Léry, Histoire d'un voyage, p. 11.

94 "Claude d'Abbeville, Capucin indigne et Indien pour le présent."

95 Vide Daher, A. Les Singularités de la France Equinoxiale. Histoire de la mission des pères capucins au Brésil (1612-1615). Paris: Honoré Champion, 2002, pp. 241-249.

${ }^{96}$ Em Jean de Léry, no oposto, a danação do selvagem e o respeito obsessivo de sua integridade física e moral são proporcionais ao fracasso da tentativa de colonização francesa do Rio de Janeiro. Lestringant afirma, além disso, que se a Histoire d'un voyage "a pu être considéré au XX' siècle comme le 'bréviaire de l'ethnologue' [cf. Claude Lévi-Strauss. Tristes Tropiques. Paris: Plon, 1955, p. 89], c'est précisément parce qu'il n'est pas un manuel d'évangélisation, moins encore un précis de colonisation" (F. Lestringant. Le Huguenot et le Sauvage, p. 49).

\section{Resumo}

$A$ atitude de tolerância frente à alteridade indigena e a representação do indio tupinambá docilmente "convertivel" contidas no relato do capuchinho Claude d'Abbeville, Histoire de la Mission... en l'isle de Maragnan (1614), são claramente tributárias do livro do huguenote Jean de Léry, Histoire d'un voyage fait en la terre du Brésil (1578). O capuchinho parafraseia o huguenote em várias passagens, mostrando o indio como objeto de análise "etnográfica", sem exclui-lo — como faz Léry — da possibilidade de salvação. Provavelmente, Claude d'Abbeville responde, desta forma, às expectativas do público francês, num contexto de exortação à colonização do Maranhão e de propaganda da obra apostólica da Ordem dos Capuchinhos.

\section{Abstract}

The attitude of tolerance toward the native otherness and the representation of the Tupinamba "convertible" with docility found in Claude d'Abbeville's Histoire de la Mission... en l'isle de Maragnan (1614) are clearly tributary of Jean de Léry's Histoire d'un voyage fait en la terre du Brésil (1578). The capuchin paraphrases the huguenot in several passages, presenting the Indian as an object of "ethnographical" analysis, 
without excluding him - as Léry does - of the possibility of salvation. Thus, Claude d'Abbeville probably answers to the expectations of the French public in a context of exhortation of the colonisation of Maranhão and promotion of the apostolic work of the Capuchin Order. 